\title{
PRELIMINARY SCREENING OF PHYTOCHEMICALS AND ANTIPROLIFERATIVE AND ANTI-INFLAMMATORY PROPERTIES OF THESPESIA POPULNEA (L.) SOLAND LEAF EXTRACTS
}

\author{
MEGHA KB, SANITH CHERIYAMUNDATH, JOSEPH MADASSERY, ELYAS KK* \\ Department of Biotechnology, University of Calicut, Malappuram, Kerala, India. Email: kkelyas@yahoo.com
}

Received: 04 August 2017, Revised and Accepted: 15 February 2018

ABSTRACT

Objective: Plant-derived bioactive molecules are providing infinite opportunities for new drug development as they possess a wide range of actions against diseases with lesser side effects. The present study is made to analyze the qualitative phytochemicals and to evaluate in vitro antiproliferative and anti-inflammatory potentials of leaf extracts of Thespesia populnea.

Methods: T. populnea leaf extracts were prepared sequentially according to the increasing polarity of the solvents, i.e., petroleum ether, chloroform, ethyl acetate, and methanol. Qualitative phytochemical analysis was performed to identify the chemical constituents of the extracts, and antiproliferative properties were evaluated against different cell lines using the 3-(4,5-dimethylthiazol-2-yl)-2,5 diphenyltetrazolium bromide assay. Bovine serum albumin anti-denaturation assay was done to identify the anti-inflammatory activity.

Results: Phytochemical analysis of the extracts revealed the presence of alkaloids, terpenoids, glycosides, tannins, flavonoids, and phenolics. The chloroform extract (CHFE) of T. populnea has a dose-dependent antiproliferative effect against acute T-cell leukemia (Jurkat E6-1), prostate Grade IV adenocarcinoma (PC-3), mouse fibroblast (L-929), and monkey kidney normal (Vero) cells. Their inhibitory concentration $50 \%$ (IC ${ }_{50}$ ) values were found to be $35.73 \pm 0.94 \mu \mathrm{g} / \mathrm{ml}$ for Jurkat E6-1, 60.79 $\pm 1.84 \mu \mathrm{g} / \mathrm{ml}$ for PC-3, 60.88 $\pm 1.45 \mu \mathrm{g} / \mathrm{ml}$ for L-929, and 83.482 $\pm 2.05 \mu \mathrm{g} / \mathrm{ml}$ for Vero, respectively. CHFE also displayed the anti-inflammatory potential.

Conclusion: The chloroform leaf extract of T. populnea possesses potent antiproliferative and anti-inflammatory activity. These properties present in leaf extract may be explained by the presence of biologically active constituents.

Keywords: Anti-inflammatory, Antiproliferative, Cancer, Phytochemical, Thespesia populnea.

(c) 2018 The Authors. Published by Innovare Academic Sciences Pvt Ltd. This is an open access article under the CC BY license (http://creativecommons. org/licenses/by/4. 0/) DOI: http://dx.doi.org/10.22159/ajpcr.2018.v11i5.21820

\section{INTRODUCTION}

Traditional system of plant-based medicine such as Ayurveda and Chinese medicines is the primary source of medications for centuries in Asia [1]. Plant-derived bioactive molecules are now becoming the thrust area of research owing to their versatile application for the development of therapeutically important drugs for several health issues. These bioactive molecules possess a wide range of action, and some of them are anticancerous, antioxidant, hepatoprotective, antibacterial, antiviral, anti-inflammatory, and antipyretic.

Cancer is a complex multifactorial disease characterized by abnormal increase in cell proliferation which is a leading cause of mortality and morbidity worldwide. Approximately $60 \%$ of drugs currently used for cancer treatment have been isolated from natural products, and the plant kingdom has been the most significant source [2].

Inflammation is a very frequent symptom of many chronic diseases. It is a protective mechanism of our body toward a tissue injury as well as for the initiation of the healing process for the tissue [3]. Non-steroidal antiinflammatory drug is commonly used for managing inflammation, but these drugs are associated with many side effects such as gastric irritation and ulcer [4]. Drugs from plants are easily available, less expensive, safe, and efficient and rarely have side effects [5]. These natural remedies have proven to play an important role in the prevention of development and in the treatment of chronic inflammatory-driven diseases [6].

Thespesia populnea (L.) Soland (family: Malvaceae) is a large avenue tree found in the tropical regions and coastal forests in India. The bark, leaves, flowers, and fruits are useful in cutaneous infection [7], and alcoholic seed extract was evaluated for hypoglycemic and antihyperglycemic [8], astringent, and hepatoprotective [9] properties. To the best of our knowledge, this is the first report on identification of various phytochemicals in polarity-based solvent extraction of leaves of T. populnea. Leaves are the most easily obtainable and preserved part of plants for secondary metabolites. Hence, an effort was made to evaluate the various phytochemicals present in the leaf extracts of T. populnea and its antiproliferative and anti-inflammatory property by an in vitro approach.

\section{METHODS}

\section{Plant material}

Matured leaves of $T$. populnea were collected and authenticated by Dr. A.K. Pradeep, Department of Botany, University of Calicut, Kerala, India. The voucher specimen with an accession number-6934 was deposited in the herbarium at the same department.

\section{Fluorescence analysis and behavior of leaf powder}

The fully matured leaves of T. populnea were collected, washed thoroughly, shade dried and coarsely powdered, and were analyzed under daylight, short ultraviolet (UV) light, long UV light as such, and also after treatment with various organic/inorganic reagents such as $\mathrm{NaOH}, \mathrm{HCl}$, and $\mathrm{H}_{2} \mathrm{SO}_{4}[10]$ (Sisco Research Laboratory, Mumbai, India). Behavior of T. populnea leaf powder with different chemical reagents was performed to detect the occurrence of phytoconstituents along with color changes under daylight by standard method [11]

Preparation and determination of percentage yield of leaf extracts The leaf powder was extracted sequentially using petroleum ether, chloroform, ethyl acetate, and methanol (Extra pure AR, Sisco Research 
Laboratory, Mumbai, India) solvents with their increasing polarity under room temperature with constant shaking for $48 \mathrm{~h}$. The extracts were filtered and each filtrate was evaporated to dry. The percentage yield of the plant extracts was also calculated. The dried petroleum ether extract (PEE), chloroform extract (CHFE), ethyl acetate extract (EAE), and methanol extract (MOHE) were used in the present study.

\section{Qualitative phytochemical analysis}

The leaf extracts (PEE, CHFE, EAE, and MOHE) of T. populnea thus prepared sequentially were tested for the presence of bioactive compounds using standard methods [12-14].

\section{Tests for proteins}

- Biuret's test: To $1 \mathrm{ml}$ of hot aqueous extract, 5-8 drops of $10 \%$ sodium hydroxide solution and followed by 1 or 2 drops of $3 \%$ copper sulfate solution were added and mixed. Formation of violet red color denotes the presence of proteins.

- Ninhydrin test: Crude extract when boiled with $2 \mathrm{ml}$ of $0.2 \%$ solution of ninhydrin. Appearance of violet color confirms the presence of amino acids and proteins.

\section{Tests for carbohydrates}

-Molisch'stest:Crudeextractwere mixed with $2 \mathrm{ml}$ ofMolisch's

reagent and shaken properly immediately $2 \mathrm{ml}$ of concentrated $\mathrm{H}_{2} \mathrm{SO}_{4}$ was poured carefully along the sides of the test tube. Appearance of a violet ring at the interphase indicates the presence of carbohydrate.

- Iodine test: $1 \mathrm{ml}$ of crude extracts was mixed with $2 \mathrm{ml}$ of iodine solution. The presence of carbohydrate is indicated by dark blue or purple coloration.

- Benedict's test: Crude extracts when mixed with 2 ml of Benedict's reagent and boiled, a reddish brown precipitate formed when carbohydrates are present.

\section{Tests for alkaloids}

- Dragendorff's reagent test: To $1 \mathrm{ml}$ of the extract, $2 \mathrm{ml}$ of Dragendorff's reagent was added and mixed. To this, $2 \mathrm{ml}$ of dilute $\mathrm{HCl}$ was added. Formation of an orange color precipitate indicates the presence of alkaloids.

- Mayer's test: Few drops of Mayer's reagent were added to the $1 \mathrm{ml}$ of extract. Formation of cream color precipitate indicates the presence of alkaloids.

- Wagner's test: To $1 \mathrm{ml}$ of extract, equal volume of Wagner's reagent was added. Formation of reddish brown precipitate indicates the presence of alkaloids.

\section{Tests for glycosides}

- Keller-Killiani's test: The extracts $(1 \mathrm{ml})$ were dissolved in $1 \mathrm{ml}$ of glacial acetic acid and cooled; after cooling, 2-3 drops of ferric chloride were added. To this solution, $2 \mathrm{ml}$ of concentrated $\mathrm{H}_{2} \mathrm{SO}_{4}$ was added carefully along the walls of the test tube. Appearance of reddish brown-colored ring at the junction of two layers indicates the presence of glycosides.

- Molisch's test: To the extracts, few drops of Molisch's reagent were added and mixed well. To this, few drops of concentrated $\mathrm{H}_{2} \mathrm{SO}_{4}$ was added carefully. Formation of reddish purple-colored ring at the junction of two layers indicates the presence of glycosides.

- Concentrated $\mathrm{H}_{2} \mathrm{SO}_{4}$ : To $1 \mathrm{ml}$ of test solution, $1 \mathrm{ml}$ of concentrated $\mathrm{H}_{2} \mathrm{SO}_{4}$ was added and allowed to stand for $2 \mathrm{~min}$. A reddish purplecolored ring at the junction of two layers signifies the occurrence of glycosides.

\section{Tests for tannins}

- Ferric chloride test: Few drops of ferric chloride solution were added to the test solution. Blackish precipitate indicates the presence of tannins.

- Gelatin test: The extracts were treated with few drops of gelatin solution. Formation of a white precipitate confirms the tannin.

- Lead acetate test: Basic lead acetate solution was added separately to $1 \mathrm{ml}$ of test solution, and bulky red precipitate confirms the presence of tannins.
- Alkaline reagent test: To the extracts $(1 \mathrm{ml})$, a solution of $\mathrm{NaOH}$ was added. The presence of tannins can be confirmed by the yellow-tored coloration.

\section{Tests for phenols}

- $\quad$ Ellagic acid test: The extracts were treated with few drops of 5\% glacial acetic acid followed by $5 \% \mathrm{NaNO}_{2}$ solution. Formation of muddy brown color confirms the presence of phenols.

- Phenol test: To the extracts, $1 \mathrm{ml}$ of ferric chloride solution was added. The development of intense coloration indicates the presence of phenols.

Tests for sterols

- Salkowski's test: To the test solutions, $5 \mathrm{ml}$ of chloroform was added. To the above mixture, $1 \mathrm{ml}$ of concentrated $\mathrm{H}_{2} \mathrm{SO}_{4}$ was added carefully along the walls of the tube and mixed. The reddish color formation in the lower layer is the indication of steroids.

Tests for terpenoids

- To 1-2 ml of extracts, $1 \% \mathrm{HCl}$ was added and allowed to stand for 5-6 h. Later, these extracts were treated with $1 \mathrm{ml}$ of Trim-Hill reagent and heated in a boiling water bath for 5-10 min. Formation of bluishgreen color confirms the presence of terpenoids.

\section{Tests for flavonoids}

- Shinoda's test: To the $1 \mathrm{ml}$ of the test solution, few fragments of magnesium ribbon were added. Then, concentrated $\mathrm{HCl}$ was added carefully along the sides of the test tube dropwise. Crimson red color indicates flavonoids.

- Lead acetate test: Basic solution of lead acetate was added separately to $1 \mathrm{ml}$ of test solutions. Bulky reddish brown precipitate confirms the presence of flavonoids.

- $\quad$ Alkaline reagent test: The test solutions were treated with sodium hydroxide solution. Flavonoid presence is obtained by a yellow-tored color change.

\section{Tests for coumarins}

- The extracts were treated separately by covering with a piece of paper soaked in $\mathrm{NaOH}$ and heated. When the tubes yield a yellow fluorescence under UV light after treatment indicates the presence of coumarins.

\section{Tests for anthraquinones}

- $1 \mathrm{ml}$ of extract was mixed with equal volumes of benzene, and then, about $1 \mathrm{ml}$ of $10 \%$ ammonia solution was added. Formation of red color on addition of ammonia gives a clear evidence for anthraquinone.

Tests for phlobatannins

- $\quad 2-3 \mathrm{ml}$ of $10 \% \mathrm{HCl}$ was added to $10 \mathrm{ml}$ of extract in a boiling tube, and the contents were boiled for 5-6 min. Formation of red color precipitate indicates the presence of phlobatannins.

Tests for resins

- To the extracts, 2-3 ml of copper sulfate solution was added mixed well for about 2 min and then allowed to separate. Resins were indicated by green color precipitate.

Tests for quinones

- Extracts were treated separately with alcoholic KOH solution. Appearance of colors ranging from red to blue indicates the presence of quinones.

Tests for fixed oils

- Small quantity of extract was taken and pressed between two Whatman No. 1 filter papers. The stain on the filter paper indicates the presence of fixed oils.

Tests for saponins

- $5 \mathrm{ml}$ of each extract is taken in separate test tube and shaken vigorously to obtain a stable froth. Saponins are confirmed by a stable froth.

\section{Cell culture}

Cell lines used in the present study were obtained from NCCS, Pune, India. Jurkat clone E6-1 (acute T-cell leukemia), PC-3 (prostate Grade IV adenocarcinoma), L-929 (mouse fibroblast), and Vero (monkey kidney 
normal cell) were used to check the cell viability. All the cell lines were maintained in the recommended medium supplemented with $10 \%$ heatinactivated fetal bovine serum (Gibco 10270, South American origin) with gentamicin $40 \mu \mathrm{g} / \mathrm{ml}$, streptomycin $100 \mu \mathrm{g} / \mathrm{ml}$, and penicillin $50 \mathrm{IU} / \mathrm{ml}$ (Hi Media, India) and were grown at $37^{\circ} \mathrm{C}$ in a humidified atmosphere of $5 \% \mathrm{CO}_{2}$ (BB15, Thermo Electron Corporation).

\section{Cell viability assay 3-(4,5-dimethylthiazol-2-yl)-2,5 diphenyltetrazolium bromide (MTT)}

Cell proliferation was measured using MTT assay [15] which is based on the reduction of MTT by the mitochondrial dehydrogenase of intact cells to a purple formazan product [16]. The method in brief, the cells were seeded in a 96-well cell culture plate with a density of 15000 cells/well and incubated overnight. After incubation, fresh medium containing varying concentration of extracts $(10-100 \mu \mathrm{g} / \mathrm{ml})$ was added to respective wells and incubated for $48 \mathrm{~h}$ in a $\mathrm{CO}_{2}$ incubator. At the end of incubation period, medium was aspirated and replaced with new media containing MTT $(5 \mathrm{mg} / \mathrm{ml})$ and incubated for 3-4 h. The formazan crystals thus formed were dissolved in dimethyl sulfoxide (Sisco Research Laboratory, Mumbai, India), and the absorbance was measured at $570 \mathrm{~nm}$ (MULTISKAN EX, Thermo Scientific) $[17,18]$. The experiments were done triplicates, and the $\mathrm{IC}_{50}$ values were calculated using the ED50 plus V1.0 Software Program.

\section{Evaluation of in vitro anti-inflammatory activity}

The anti-inflammatory activity of the leaf extracts was done using bovine serum albumin (BSA)-anti-denaturation assay [19]. To $0.2 \mathrm{ml}$ of extract solution/standard prepared in isosaline, $1.8 \mathrm{ml}$ of 1\% BSA (Sigma A-3294, St. Louis) was added. This solution was incubated at $57^{\circ} \mathrm{C}$ for $10-15 \mathrm{~min}$. After cooling, the turbidity was measured at $660 \mathrm{~nm}$. Diclofenac sodium (Novartis, India) was used as standard. The experiments were performed in triplicates and their $\mathrm{IC}_{50}$ values were calculated.

\section{RESULTS}

Fluorescence analysis and behavior of T. populnea leaf powder Fluorescence characteristics of leaf powder of T. populnea were observed in visible, short, and long UV light (Table 1). This can be used for checking the resolution of doubtful specimen. The occurrence of different phytoconstituents can be detected by after reacting the leaf powder with different chemical reagents. It showed the presence of alkaloids, terpenoids, glycosides, tannins, flavonoids, and phenolics (Table 2).

Extractive values of the extracts and their phytochemical analysis T. populnea leaf powder was sequentially extracted using solvents such as petroleum ether, chloroform, ethyl acetate, and methanol based on their increasing polarity. The extracts were filtered and dried; their extractive value and consistency are depicted in Table 3. These extracts are subjected for preliminary phytochemical analysis and reveal the presence of various types of phytoconstituents such as alkaloids, terpenoids, glycosides, tannins, flavonoids and phenolics (Table 4).

\section{Assessment of cell proliferation (MTT assay)}

To evaluate the cytotoxic effect of the sequentially prepared extracts of T. populnea on Jurkat (acute T-cell leukemia), PC-3 (prostate Grade IV, adenocarcinoma), L-929 (mouse fibroblast), and Vero (monkey kidney normal cell), the cells were treated with different concentrations of drug ranging from 10 to $100 \mu \mathrm{g} / \mathrm{ml}$ for $48 \mathrm{~h}$ of incubation, and the cell viability was determined by MTT assay. CHFE inhibited the viability in all the tested cell lines in a dose-dependent manner, and the other extracts did not display much enhancing cytotoxicity. The $\mathrm{IC}_{50}$ values of $\mathrm{CHFE}$ on different cells were calculated and were found to be $35.73 \pm 0.94 \mu \mathrm{g} /$ $\mathrm{ml}$ for Jurkat E6-1, $60.79 \pm 1.84 \mu \mathrm{g} / \mathrm{ml}$ for PC-3, $60.88 \pm 1.45 \mu \mathrm{g} / \mathrm{ml}$ for $\mathrm{L}-929$, and $83.482 \pm 2.05 \mu \mathrm{g} / \mathrm{ml}$ for Vero, respectively (Fig. 1). All the experiments were done in triplicates, and the data were expressed as mean \pm standard deviation (SD).

\section{BSA anti-denaturation assay}

The denaturation of proteins is well-documented cause of inflammation. As a part of the study, anti-inflammatory activity of the leaf extracts of T. populnea was checked, using BSA anti-denaturation assay with diclofenac sodium as standard. The CHFE only showed inhibition to BSA denaturation in a concentration-dependent manner (100-1000 $\mu \mathrm{g} / \mathrm{ml})$.

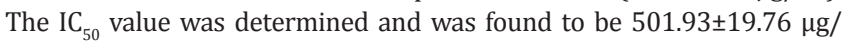
$\mathrm{ml}$ for CHFE and $175.909 \pm 9.37 \mu \mathrm{g} / \mathrm{ml}$ for diclofenac sodium (Fig. 2). The experiments were done in triplicates, and the data were represented as mean \pm SD.

\section{DISCUSSION}

Plants are lauded for their diverse pharmacological actions which could be attributed to the presence of numerous secondary metabolites such as alkaloids, glycosides, tannins, and steroids. Better understanding of the secondary metabolites is necessary for development of a new molecular entity. In the present study, preliminary qualitative phytochemical analysis confirmed the presence of alkaloids, terpenoids, glycosides, tannins, flavonoids, and phenolics in different leaf extracts of T. populnea.

Plants have a long history of use in the treatment of cancer providing some of the currently using effective anticancer agents such as vinblastine, vincristine, mechlorethamine, etoposide, teniposide, paclitaxel, bleomycin, cisplatin, and taxanes [20-23]. However, cancerrelated death will be projected to increase to over 11 million in 2030 (World Health Organization, 2010). The need for more effective anticancerous agents remains an active research due to the resistance

Table 1: Fluorescence analysis of powdered leaf of T. populnea

\begin{tabular}{|c|c|c|c|}
\hline \multirow[t]{2}{*}{ Treatment } & \multicolumn{3}{|c|}{ Color observed } \\
\hline & Daylight & $\begin{array}{l}\text { UV light } \\
\text { short, } 254 \text { nm }\end{array}$ & $\begin{array}{l}\text { UV light long, } \\
365 \mathrm{~nm}\end{array}$ \\
\hline Powder as such & Green & Green & Green \\
\hline $\begin{array}{l}1 \mathrm{~N} \mathrm{NaOH} \text { in } \\
\text { methanol }\end{array}$ & Green & Green & Orange \\
\hline $1 \mathrm{~N} \mathrm{HCl}$ & Green & Green & Light green \\
\hline $1 \mathrm{~N} \mathrm{NaOH}$ in water & Brown & Black & Brown \\
\hline Powder $+\mathrm{H}_{2} \mathrm{SO}_{4}$ & Brown & Black & Blue \\
\hline
\end{tabular}

Leaf powder was analyzed under daylight and short and long UV light after treatment with various organic and inorganic reagents to obtain a significant color. T. populnea: Thespesia populnea, UV: Ultraviolet

Table 2: Behavior of T. populnea leaf with different chemical reagents

\begin{tabular}{|c|c|c|}
\hline Reagents & Color/precipitate & Constituents \\
\hline Picric acid & Precipitate formed & Alkaloids present \\
\hline Concentrated & Reddish brown & Steroids/ \\
\hline $\mathrm{H}_{2} \mathrm{SO}_{4}$ & & triterpenoids present \\
\hline Aqueous $\mathrm{FeCl}_{3}$ & Black precipitate & Tannins present \\
\hline Iodine solution & No change & Starch absent \\
\hline Mayer's reagent & Precipitate formed & Alkaloids present \\
\hline Aqueous $\mathrm{NaOH}$ & Yellow color & Flavonoids present \\
\hline Mg-HCl (Shinoda) & Dark pink color & Flavonoids present \\
\hline $\begin{array}{l}\text { Dragendorff's } \\
\text { reagent }\end{array}$ & $\begin{array}{l}\text { Dark brown } \\
\text { precipitate }\end{array}$ & Alkaloids present \\
\hline Ninhydrin & $\begin{array}{l}\text { Pale white } \\
\text { precipitate }\end{array}$ & $\begin{array}{l}\text { Proteins/amino acids } \\
\text { present }\end{array}$ \\
\hline
\end{tabular}

Leaf powder was reacted with different reagents to detect the occurrence of phytoconstituents with color change under daylight. T. populnea, Thespesia populnea

Table 3: Extractive values of the extract

\begin{tabular}{llll}
\hline Extract & \% of yield & Color & Consistency \\
\hline Petroleum ether & 1.79 & Yellowish green & Greasy \\
Chloroform & 3.14 & Dark green & Sticky \\
Ethyl acetate & 0.506 & Brownish green & Sticky \\
Methanol & 10.50 & Brown & Syrupy \\
\hline
\end{tabular}

Leaf powder extracted with solvents of increasing polarity and their $\%$ of yield was noted 
toward the chemotherapeutics with fewer side effects. Here, an approach was made to check the antiproliferative property of leaf extracts of T. populnea as leaf is the easily available part for the sustainable

Table 4: Preliminary phytochemical analysis of T. populnea leaf extracts

\begin{tabular}{|c|c|c|c|c|}
\hline Phytochemical test & PEE & CHFE & EAE & MOHE \\
\hline \multicolumn{5}{|l|}{ Tests for proteins } \\
\hline Biuret's test & - & - & - & - \\
\hline Ninhydrin test & - & - & - & - \\
\hline \multicolumn{5}{|l|}{ Tests for carbohydrates } \\
\hline Molisch's test & + & + & + & + \\
\hline Iodine test & - & - & - & - \\
\hline Benedict's test & - & ++ & ++ & ++ \\
\hline \multicolumn{5}{|l|}{ Tests for alkaloids } \\
\hline Dragendorff's test & - & ++ & ++ & - \\
\hline Mayer's test & ++ & - & - & + \\
\hline Wagner's test & ++ & ++ & ++ & ++ \\
\hline \multicolumn{5}{|l|}{ Tests for glycosides } \\
\hline Keller-Killiani's test & + & ++ & + & ++ \\
\hline Molisch's test & + & ++ & ++ & + \\
\hline Concentrated $\mathrm{H}_{2} \mathrm{SO}_{4}$ & - & ++ & ++ & ++ \\
\hline \multicolumn{5}{|l|}{ Tests for tannins } \\
\hline Ferric chloride test & - & ++ & ++ & + \\
\hline Gelatin test & ++ & + & - & + \\
\hline Lead acetate test & - & - & + & - \\
\hline Alkaline reagent test & - & ++ & ++ & + \\
\hline \multicolumn{5}{|l|}{ Tests for phenols } \\
\hline Ellagic acid test & - & ++ & ++ & + \\
\hline Phenol test & - & ++ & ++ & + \\
\hline \multicolumn{5}{|l|}{ Tests for sterols } \\
\hline Salkowski's test & - & ++ & - & - \\
\hline Tests for terpenoids & - & ++ & ++ & - \\
\hline \multicolumn{5}{|l|}{ Tests for flavonoids } \\
\hline Shinoda's test & - & - & - & ++ \\
\hline Lead acetate test & - & + & ++ & + \\
\hline Alkaline reagent test & - & ++ & ++ & + \\
\hline Tests for coumarins & ++ & - & - & - \\
\hline Tests for anthraquinones & - & ++ & ++ & + \\
\hline Tests for phlobatannins & - & - & - & + \\
\hline Tests for resins & - & ++ & ++ & - \\
\hline Tests for quinines & - & ++ & ++ & + \\
\hline Tests for fixed oils & ++ & - & + & ++ \\
\hline Tests for saponins & - & - & - & ++ \\
\hline
\end{tabular}

++ - Strongly present, + - present, - - absent. PEE: Petroleum ether extract, CHFE: Chloroform extract, EAE: Ethyl acetate extract, MOHE: Methanol extract, T. populnea, Thespesia populnea

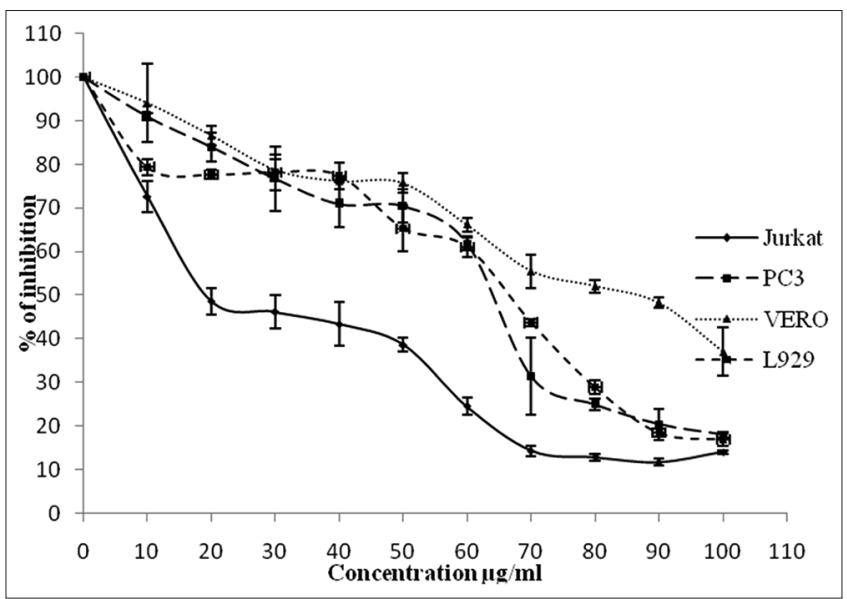

Fig. 1: The graph representing the percentage inhibition on Jurkat E6-1, PC-3, L-929, and Vero cells after $48 \mathrm{~h}$ of treatment using chloroform extract of different concentration (10-100 $\mathrm{\mu g} / \mathrm{ml})$ by 3-(4,5-dimethylthiazol-2-yl)-2,5 diphenyltetrazolium bromide assay. Values are expressed in mean \pm standard deviation $(n=3)$

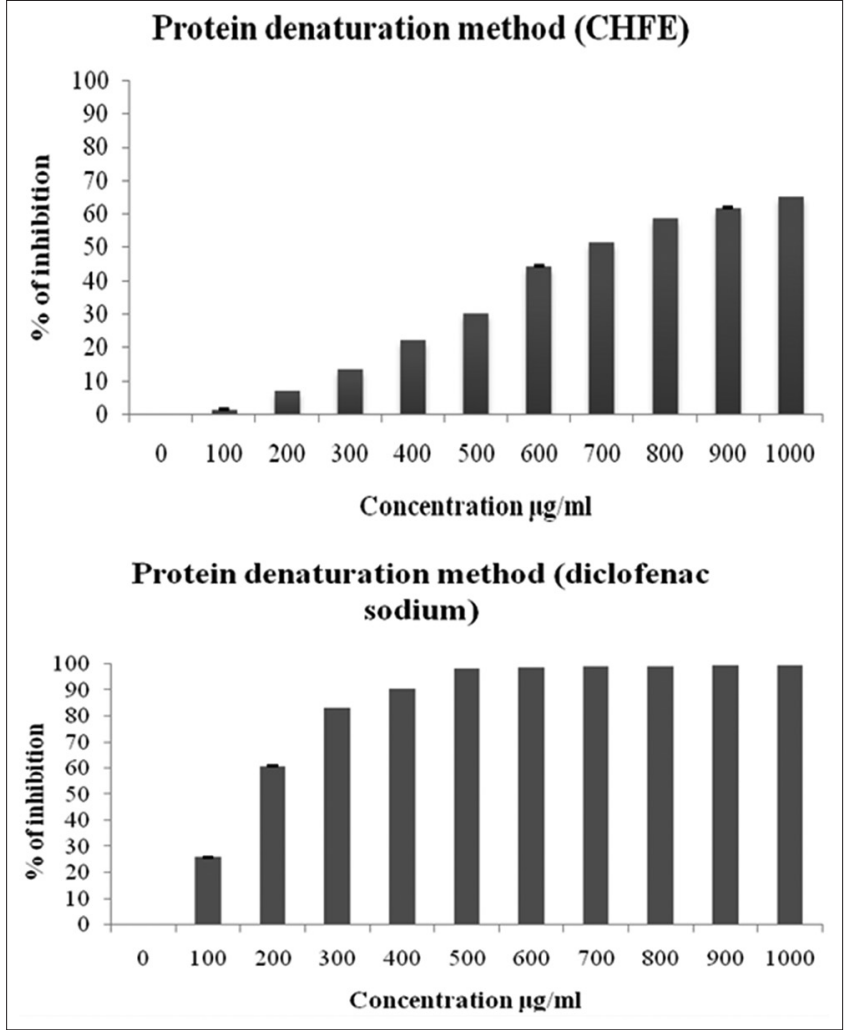

Fig. 2: Bovine serum albumin-anti-denaturation assay for checking the anti-inflammatory activity of chloroform extract and standard drug diclofenac sodium. Values are expressed in mean \pm standard deviation $(n=3)$

exploration for secondary metabolites. The antiproliferative property of the leaf extracts was screened by MTT assay out of which CHFE showed a potent dose-dependent response against Jurkat E6-1, PC-3, L-929, and Vero cell lines and is not reported yet elsewhere. A previous study reported that the extracts of heartwood and wood of T. populnea showed significant cytotoxicity against MCF-7, HeLa, HT-29, and KB cancer cell lines [24]. It has been already reported that the presence of flavonoid, saponins, terpenoids, and tannins is believed to contribute partly to their antiproliferative activity through antioxidant and free radical scavenging effects $[25,26]$. Tannins and polyphenolic compounds are useful for treating inflamed or ulcerated tissues and have remarkable cancer prevention and anticancer activity $[27,28]$. Thus, CHFE contained most of the above-mentioned phytochemical constituents, may be a potential source of very active biomolecules for treating cancer.

In traditional system, plant-based medicines are used to treat inflammatory conditions which will be a safe and viable alternative to anti-inflammatory drugs. In the present work, an attempt was made to check the antiinflammatory properties of leaf extracts of T. populnea using BSA antidenaturation assay. The CHFE showed inhibition toward protein denaturation but having a higher $\mathrm{IC}_{50}$ while comparing with that of standard diclofenac sodium. A similar study conducted by Darsan and Latha following the same method demonstrated that stem of Coleus forskohlii stabilizes the protein from denaturation process [29]. After isolating the major constituent which is attributing, this anti-inflammatory property would be a worthwhile for the development of anti-inflammatory drug therapy.

In summary, the result highlights the presence of a variety of secondary metabolites present in the leaf extracts of T. populnea and also showed the antiproliferative and anti-inflammatory properties.

\section{CONCLUSION}

On the basis of the detailed phytochemical screening, the leaf extracts of T. populnea are rich in variety of secondary metabolites and also 
exhibited the antiproliferative and anti-inflammatory activity in chloroform leaf extract of. However, purification and identification of the active compounds in this plant is required for a better understanding of the protective mechanism involved and for the possible application for new drug development.

\section{ACKNOWLEDGMENT}

We acknowledge the University of Calicut and the Department of Biotechnology, Government of India. For providing research facilities and financial support.

\section{REFERENCES}

1. Balunas MJ, Kinghorn AD. Drug discovery from medicinal plants. Life Sci 2005;78:431-41

2. Gordaliza M. Natural products as leads to anticancer drugs. Clin Transl Oncol 2007:9:767-76

3. Amir M, Javed SA, Kumar H. Design and synthesis of 3-[3-(substituted phenyl)-4-piperidin-1-ylmethyl-4-morpholin-4-ylmethyl-4,5-dihydroisoxazol-5-yl]-1H-indoles as potent anti inflammatory agents. Med Chem Res 2010;19:299-310.

4. Ashley NT, Weil ZM, Nelson RJ. Inflammation: Mechanisms costs and natural variation. Annu Rev Ecol Evol Syst 2012;43:385-406.

5. Aggarwal BB, Shishodia S. Molecular targets of dietary agents for prevention and therapy of cancer. Biochem Pharmacol 2006;71:1397- 421.

6. Yadav RN, Agarwal M. Phytochemical analysis of some medicinal plants. J Phytol 2011:3:10-4

7. Vasudevan M, Gunnam KK, Parle M. Antinociceptive and antiinflammatory effects of Thespesia populnea bark extract. J Ethnopharmacol 2007;109:264- 70

8. Belhekar SN, Pandhare RB, Gawade SP. Antihyperglycemic effect of Thespesia populnea seed extracts in normal and alloxan induced diabetic rats. J Pharm Res 2009;2:1860-3.

9. Yuvraj P, Subramoniam A. Hepatoprotective property of Thespesia populnea against carbontetra chloride induced liver damage in rats. J Basic Clin Phys Pharmacol 2009;20:169-77.

10. Kalaskar MG, Surana SJ. Pharmacognostic and phytochemical investigation of Luffa acutangula. Int J Pharm Tech Res 2010;2:1609-14.

11. Sing VK, Govil GS. Recent progress in medicinal plants. Ethnomedicine and Pharmacognosy. Vol 1. Texas: SCI Tech Publishing LIC; 2002. p. 325

12. Sofowra A. Medicinal Plants and Traditional Medicine in Africa. Nigeria: Spectrum Books Ltd; 1993. p. 191-289.

13. Trease GE, Evan WC. Pharmacognosy. $2^{\text {nd }}$ ed. London: Bailliese Tindall; 1989. p. 45-50.

14. Harbone JE. Phytochemical Methods. London: Chapman and Hall Ltd;
1973. p. 49-188.

15. Mosmann T. Rapid colorimetric assay for cellular growth and survival: Application to proliferation and cytotoxicity assays. J Immunol Methods 1983;65:55-63.

16. Raghavan R, Cheriyamundath S, Madassery J. 14-Deoxy-11,12didehydroandrographide inhibits proliferation and induces GSHdependent cell death of human promonocytic leukemic cells. J Nat Med 2014;68:387-94.

17. Mishra A, Roy S, Maity S, Yadav RK, KeshariAK, Saha S. Antiproliferative effect of flower extracts of Spilanthus paniculata on hepatic carcinoma cells. Int J Pharm Pharm Sci 2015;7130-4.

18. Mutiah R, Sukardiman, Widyawaruyanti AT. Cytotoxic effect of crude extract and fraction from Calotropis gigantea leaves on human colon cancer widr cell lines. Int J Pharm Pharm Sci 2017;9:83-6.

19. Grant NH, Alburn HE, Kryzanauskas C. Stabilization of serum albumin by anti-inflammatory drugs. Biochem Pharmacol 1970;19:715-22.

20. De Vita VT, Serpick AA, Carbone PP. Combinational chemotherapy in the treatment of advanced Hodgkin's disease. Ann Intern Med 1970;73:881-95.

21. Stahelin H. Activity of a new glycosidic lignin derivative (VP16213) related to podophyllotoxin in experimental tumors. Eur J Cancer $1973 ; 9: 215-21$

22. Greco FA, Loehrer PJ. Treatment of disseminated germ-cell tumors with cisplatin, bleomycin and either vinblastine or etoposide. N Engl J Med 1987;316:1435-40

23. Wani MC, Taylor HL, Wall ME, Coggon P, McPhail AT. Plant antitumor agents. VI. The isolation and structure of Taxol, a novel antileukemic and antitumor agent from Taxus Brevifolia. J Am Chem Soc 1971;93:2325-7

24. Sompong B, Chatchanok K, Chanita P, Suchada C, Akkharawit KO. Cytotoxic and antibacterial sesquiterpenes from Thespesia populnea. J Nat Prod 2008;71:1173-7.

25. Mithraja MJ, Antonisamy JM, Mahesh M, Paul ZM, Jeeva S. Phytochemical studies on Azolla pinnata R. Br., Marsilea minuta L. and Salvinia molesta Mitch. Asian Pac J Trop Biomed 2011;1:S26-9.

26. Zakaria ZA, Rofiee MS, Mohamed AM, Teh LK, Salleh MZ. In vitro antiproliferative and antioxidant activities and total phenolic contents of the extracts of Melastoma malabathricum leaves. J Acupunct Meridian Stud 2011;4:248-56

27. Aiyegoro OA, Okoh AI. Phytochemical screening and polyphenolic antioxidant activity of aqueous crude leaf extract of Helichrysum pedunculatum. Int J Mol Sci 2009;10:4990-5001.

28. Aiyegoro OA, Okoh AI. Preliminary phytochemical screening and in vitro antioxidant activities of the aqueous extract of Helichrysum longifolium DC. BMC Complement Altern Med 2010;10:21.

29. Darsan BM, Latha K. Phytochemical screening and in vitro antiinflammatory activity of the stem of Coleus forskohlii. Pharm J 2011;3:75-9. 